\title{
Epidemiological study and spatial modeling of peste des petits ruminants (PPR) in central area of Iran
}

\author{
Estudio epidemiológico y modelación espacial de peste de \\ pequeños rumiantes (PPR) en el área central de Irán
}

\author{
Azam Mokhtari* Ph.D, Zahra Azizi² Ph.D, Soheila Rabiaee Fradonbeh1 Ph.D.
}

\begin{abstract}
1University of Shahrekord, Faculty of Veterinary Medicine, Department of pathobiology, Shahrekord, Iran. 2Islamic Azad University, Science and Research Branch, Faculty of Environment and Energy, Department of RS and GIS, Tehran, Iran. *Correspondence: a.mokhtari@alumni.ut.ac.ir
\end{abstract}

Received: July 2016; Accepted: January 2017.

\begin{abstract}
Objective. Estimate the prevalence and spatial modeling of PPR in the small ruminant population of Chaharmahal and Bakhtiari, Iran, during 2009-2014. Materials and methods. Data were collected from veterinary organization and Offices in Chaharmahal and Bakhtiari province and data analysis was carried out using and IBM SPSS version 22 and Office 2010. For spatial modeling geographic information system (QGIS and PCI-Geomatic) was used. Results. This study showed that the overall prevalence of PPR during the years 2009 to 2014 was 1.37\%. Koohrang, Ardal, Lordegan, Ben, Borougen, Shahrekord, Farsan and Kiar cities had the highest prevalence of PPR, respectively. The highest PPR infection rate was observed in the March and goat more affected rather than other ruminants. Conclusions. Our findings provide evidence of a rather common prevalence of PPR and its spatial distribution in Chaharmahal and Bakhtiari province. Using statistical tests for data analysis of PPR and its spatial modeling researchers can predict the incidence of disease in the future and could select appropriate measures of disease control.
\end{abstract}

Keywords: Epidemiology, peste des petits, prevalence, spatial modeling (Source:CAB).

\section{RESUMEN}

Objetivo. Estimar la prevalencia y el modelo espacial de PPR en la población de pequeños rumiantes de Chaharmahal y Bakhtiari, Irán, durante los años 2009-2014. Materiales y métodos. Los datos fueron recolectados de la organización veterinaria y las oficinas en la provincia de Chaharmahal y Bakhtiari y el análisis de datos se llevó a cabo utilizando IBM SPSS versión 22 y Office 2010. Para el sistema de información geográfica de modelado espacial se utilizó QGIS y PCI-Geomatic. Resultados. Este estudio mostró que la prevalencia general de PPR durante los años 2009 a 2014 fue de 1.37\%. Las ciudades de Koohrang, Ardal, Lordegan, Ben, Borougen, Shahrekord, Farsan y Kiar tuvieron la mayor prevalencia de PPR, respectivamente. La mayor tasa de infección por PPR se observó en marzo y cabra más afectados que otros rumiantes. Conclusiones. Nuestros resultados proporcionan evidencia de una prevalencia bastante común de PPR y su distribución espacial en Chaharmahal y Bakhtiari provincia. El uso de pruebas estadísticas para el análisis de datos de PPR y su modelado espacial los investigadores pueden predecir la incidencia de la enfermedad en el futuro y podría seleccionar las medidas adecuadas de control de la enfermedad.

Palabras clave: Epidemiología, modelación espacial, peste des petits, prevalencia (Fuente:CAB). 


\section{INTRODUCTION}

Peste des petits ruminants (PPR) is a highly contagious viral disease of sheep and goats (1). The World Organization for Animal Health has identified PPR as a remarkable and economically important worldwide viral disease of small ruminants associated with high morbidity and mortality $(2,3)$. This particular disease had a course of per acute, acute or may be chronic and its fatality rate may be very high (4). Clinically, manifestations of this disease include severe pyrexia, oculo-nasal discharges, necrotizing and erosive stomatitis, enteritis, and pneumonia. PPR virus (PPRV), is genetically grouped into four lineages (I, II, III, and IV) based on partial sequence analysis of the fusion $(F)$ gene and $\mathrm{N}$ gene $(5,6)$. PPR is a member of morbillivirus genus of paramyxoviridae family. The disease was first described in 1942 in the Ivory Coast of West Africa and was later reported in other parts of the world (6). Episodes associated with PPR are usually occur inside India, Nepal, Bangladesh, Pakistan, Bhutan and Afghanistan (5,7-10). In Asia, PPR was first reported in Pakistan in early 1990s on the bases of clinical and epidemiological observations (11) and it was confirmed through laboratory assays by Amjad et al in $1996(6)$. The morbidity rate can reach levels of $80-90 \%$ in naïve herds and mortality rate varies from $50 \%$ to $80 \%$ (9). In non-endemic areas mortality and morbidity rates may range depending upon sensitive population and in severe cases can reach up to $90 \%$ and $100 \%$, respectively. Superinfections with other bacterial, viral or parasitic agents may increase mortality up to $100 \%(12)$.

Information on prevalence of PPR disease is available from a number of countries in which the disease has been reported such as Asian countries $(13,14)$. However, the pattern of PPR disease, prevalence and underlying risk factors in Chaharmahal and Bakhtiari province of Iran has not been analyzed before. Also, no systematic study of PPRV infection has been done in small ruminants from Iran. The clinical prevalence of PPR among ruminants could be of epidemiological significance, and data about PPR outbreaks are necessary for effective disease management. Therefore, the current study was performed to analyze baseline data to determine the PPR prevalence of PPR in Chaharmahal and Bakhtiari province of Iran over a period of 6 years.

\section{MATERIALS AND METHODS}

Data collection. This research was a crosssectional study that was performed during the years 2009 to 2015. In this study, data of PPR

\section{INTRODUCCIÓN}

La Peste de los pequeños rumiantes (PPR) es una enfermedad viral altamente contagiosa presente en ovinos y caprinos (1). La Organización Mundial de Sanidad Animal ha identificado a la PPR como una enfermedad viral en pequeños rumiantes notable y de importancia a nivel global, que está asociada a elevadas tasas de morbilidad y mortalidad $(2,3)$. Esta enfermedad en particular tuvo un curso de hiperaguda, aguda o posiblemente crónica y su tasa de mortalidad puede ser muy alta (4). Desde una perspectiva clínica, las manifestaciones de esta enfermedad incluyen pirexia severa, descargas oculo-nasales, estomatitis necrotizante y erosiva, enteritis y neumonía. El virus PPR (PPRV) está genéticamente agrupado en cuatro linajes (I, II, III y IV) con base en el análisis de la secuencia parcial del gen de la fusión $(F)$ y el gen $N(5,6)$. La PPR es un miembro del género morbillivirus perteneciente a la familia paramyxoviridae. La enfermedad se describió por primera vez en 1942 en Costa de Marfil en África Occidental y posteriormente fue reportado en otras partes del mundo (6). Los episodios asociados a la PPR suelen ocurrir en India, Nepal, Bangladesh, Pakistán, Bután y Afganistán (5,7-10). En Asia, la PPR fue reportada por primera vez en Pakistán a principios de los años noventa, con base en observaciones clínicas y epidemiológicas (11) y fue confirmada mediante ensayos de laboratorio realizados por Amjad et al en 1996 (6). La tasa de morbilidad puede alcanzar niveles del $80-90 \%$ en rebaños sin tratamiento previo y la tasa de mortalidad va del $50 \%$ al $80 \%$ (9). En zonas no endémicas, las tasas de mortalidad y morbilidad pueden variar según la población sensible y en casos graves pueden llegar hasta un $90 \%$ y $100 \%$, respectivamente. Las superinfecciones con otros agentes bacterianos, virales o parasitarios pueden aumentar la mortalidad hasta en un $100 \%$ (12).

Varios países en donde se ha reportado la enfermedad, como lo son los países asiáticos, disponen de información sobre la prevalencia de la enfermedad PPR $(13,14)$. Sin embargo, el patrón de la enfermedad PPR, su prevalencia y los factores de riesgo subyacentes en la provincia iraní de Chahar Mahal y Batjarí no han sido analizados antes. Además, en Irán no ha sido realizado ningún estudio sistemático acerca de la infección por PPRV en pequeños rumiantes. La prevalencia clínica de la PPR entre rumiantes podría ser de importancia epidemiológica, y los datos sobre brotes de PPR son necesarios para un manejo efectivo de la enfermedad. El presente estudio fue realizado durante un período de 6 años, para analizar los datos de referencia y así determinar la prevalencia de PPR en la provincia iraní de Chahar Mahal y Batjarí. 
cases were recorded by veterinary centers in Chaharmahal and Bakhtiari Province and data were collected during 2009 to 2014. Veterinary centers in Iran used ELISA test using monoclonal antibodies (MAb) raised to the $\mathrm{N}$ protein for diagnosing PPR disease in addition to clinical symptoms. Several homologous PPR vaccines are available in Iran, being cell culture-attenuated strains of natural PPRV. Although transmission of the live attenuated PPR vaccine strain in the field cannot be completely ruled out, there is currently no evidence for vaccine strain transmission either in the field or through experimental infection studies (15). All animals at the various locations are monitored for 12 weeks post-vaccination both by regular weekly visits and with the aid of the local veterinarian for evidence of PPR or any other illness in any of the experimental animals. In this study, the simultaneous presence of a positive result in the ELISA test with clinical signs of the disease was necessary for considering an animal as a PPR case. Then all of information contains location of outbreaks (latitude and longitude), time of occurrence (month, season and year), host species of sick animals, social and political divisions of locations, type of herds, the total number of farms, the number of examined and affected animals and the number of dead patients recorded. Animals tested during the period of this study included cattle, sheep and goat. The cities where the disease monitored included Koohrang, Borujen, Shahrekord, Kiar, Ardal, Farsan, Ben and Lordegan.

Chaharmahal and Bakhtiari province generally has a cold and dry climate. Although in winter, there is a high rainfall especially in Kouhrang city. In the study more than two hundred villages that were suspected for PPRV infection was surveyed.

Statistical analysis. Data were classified using Microsoft Excel 2010 and were analyzed using IBM SPSS version 22. For all of analyses Chisquare test was selected.

Spatial modeling. Spatial modeling was performed using GIS software. Physiographic information, distance from water sources and sanitation and distance from urban residential areas were used for modeling. Maps describing the pattern of disease distribution was made and interpreted.

\section{RESULTS}

Out of 2231475 animals, 911145 were checked from 2009 to 2014. The results of this study showed that the overall prevalence of PPR was $1.37 \%$ (12518). The spatial distribution of

\section{MATERIALES Y MÉTODOS}

Recolección de datos. Esta investigación consistió de un estudio transversal realizado entre los años 2009 y 2015. En el presente estudio, los datos relativos a casos de PPR fueron registrados por los centros veterinarios de la provincia de Chahar Mahal y Batjarí durante un período y la recolección de datos se llevó acabo desde el 2009 hasta el 2014. Los centros veterinarios en Irán utilizaron la prueba de ELISA mediante anticuerpos monoclonales (MAb) elevados a la proteína N para diagnosticar la enfermedad de PPR además de los síntomas clínicos. Varias vacunas de PPR homólogas se encuentran disponibles en Irán, dado que son cepas de PPRV natural atenuadas por cultivo celular. Aunque no se puede descartar por completo la transmisión en el campo de la cepa de la vacuna contra la PPR viva atenuada, en la actualidad no existe evidencia alguna para indicar que la transmisión de la cepa vacunal se dé en el campo ni estudios de infección experimentales (15). Los animales ubicados en distintos lugares son monitoreados durante 12 semanas después de la vacunación, por medio de visitas semanales regulares y con la ayuda de los veterinarios locales determinar la presencia de PPR o cualquier otra enfermedad en cualquiera de los animales del experimento. En el presente estudio, se considera a un animal como caso de PPR cuando existe la presencia simultánea de un resultado positivo en la prueba de ELISA y signos clínicos de la enfermedad. La información completa incluye la ubicación de los brotes (latitud y longitud), el tiempo de ocurrencia (mes, estación y año), las especies huésped en los animales enfermos, las divisiones sociales y políticas del lugar, el tipo de rebaños, la cantidad total de granjas, cantidad total de animales examinados y afectados y cantidad de pacientes muertos registrados. Los animales examinados durante el plazo del presente estudio incluyeron bovinos, ovinos y caprinos. Las ciudades en donde se examinó la enfermedad fueron Koohrang, Borujen, Shahrekord, Kiar, Ardal, Farsan, Ben y Lordegan.

La provincia iraní de Chahar Mahal y Batjarí por lo general goza de un clima frío y seco. Aunque en invierno se presentan altas precipitaciones, especialmente en la ciudad de Kouhrang. Se encuestaron más de doscientas aldeas en donde se sospechó la presencia de infección por PPRV.

Análisis estadístico. La información se clasificó utilizando Microsoft Excel 2010 y se analizó utilizando IBM SPSS versión 22. La prueba de Chicuadrado fue seleccionada para todos los análisis.

Modelado espacial. El modelado espacial fue realizado con el software GIS. La información fisiográfica, la distancia de las fuentes de agua 
morbidity rates was $0.94 \%$ in Farsan, $0.64 \%$ in Kiar, $1.65 \%$ in Lordegan, $1.76 \%$ in Ardal, $1.375 \%$ in Ben, $0.95 \%$ in Shahrekord, $1.03 \%$ in Borujen and $2.42 \%$ in Kouhrang cities. However, with spatial modeling, the main hotspot of PPR was observed in Borujen (morbidity rate: 1.03\%), However, two other hotspot were found in Ardal and Naghan (morbidity rates: $1.76 \%$ and $4.3 \%$ respectively). With chi-square test there wasn't a statistically significant difference between morbidity rates in different cities $(p<0.05)$

Distribution of disease in different types of herds is shown in figure 1 . The prevalence of PPR in dairy- Beef cattle farms (25\%) was higher than other farms. The PPR infection rate reported in goats was $1.69 \%$ and it was higher than sheep $(1.32 \%)$. With chi-square test a statistically significant difference obtained between PPR prevalence in different types of animal farms $(p<0.05)$ (Figures 1 and 2).

PPR prevalence in different types of farms

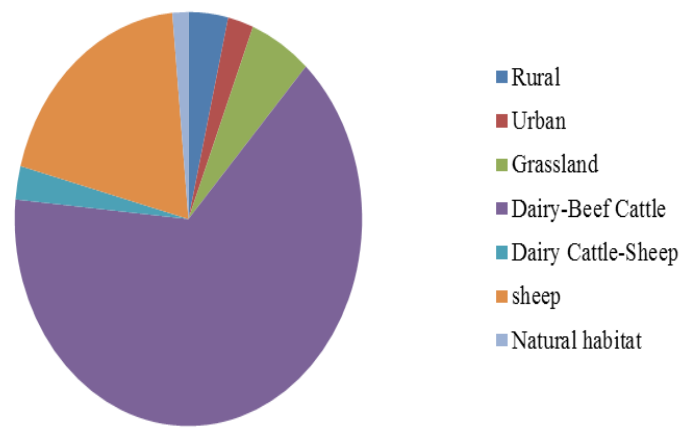

Figure 1. The distribution of PPR disease in different types of farms in Chaharmahal and Bakhtiari Province.

PPR prevalence in different species of animals

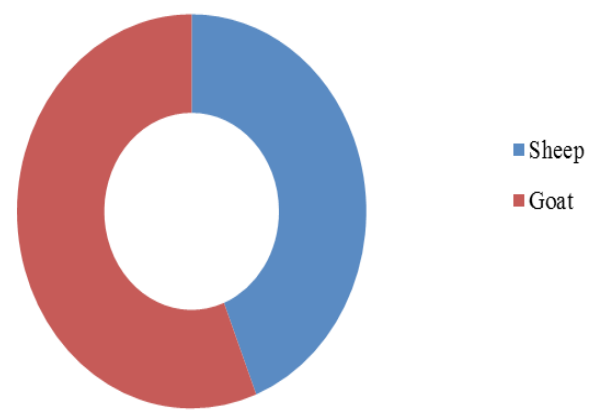

Figure 2. The distribution of PPR disease in different types of animals in Chaharmahal and Bakhtiari e instalaciones de saneamiento y la distancia de las áreas residenciales urbanas se utilizaron en el modelado. Se produjeron e interpretaron mapas que describen el patrón de distribución de la enfermedad.

\section{RESULTADOS}

De los 2231475 animales, 911145 fueron examinados de 2009 a 2014. Los resultados de este estudio mostraron que la prevalencia general de PPR fue de $1.37 \%$ (12518). La distribución espacial de las tasas de morbilidad fue de $0.94 \%$ en Farsan, $0.64 \%$ en Kiar, $1.65 \%$ en Lordegan, $1.76 \%$ en Ardal, $1.375 \%$ en Ben, $0.95 \%$ en Shahrekord, $1.03 \%$ en Borujen y $2.42 \%$ en Kouhrang. Sin embargo, por medio del modelado espacial, el principal punto focal (hotspot) de PPR se observó en Borujen (tasa de morbilidad: $1.03 \%)$, Sin embargo, otros dos puntos focales fueron encontrados en Ardal y Naghan (tasas de morbilidad: $1.76 \%$ y $4.3 \%$ respectivamente). La prueba de chi cuadrado no arrojó diferencias estadísticamente significativas entre las tasas de morbilidad en distintas ciudades $(p<0.05)$

La figura 1 muestra la distribución de la enfermedad en distintos tipos de rebaño. La prevalencia de PPR fue mayor en granjas lecheras (25\%) que en otras granjas. La tasa de infección de PPR reportada en ca fue del $1,69 \%$ y superior a la de ovejas (1,32\%). Con la prueba de chi cuadrado se obtuvo una diferencia estadísticamente significativa entre la prevalencia de PPR en distintos tipos de granjas de animales $(p<0.05)$ (Figuras 1 y 2 ).

La prevalencia de PPR de 2009 a 2014 fue de $2.1 \%, 2.59 \%, 0.7 \%, 0.49 \%, 1.08 \%, 1.73 \%$, respectivamente. La distribución estacional de la infección por PPR fue de $2,6 \%$ en la primavera, $1.55 \%$ en el verano, $0.32 \%$ en el otoño y $1.73 \%$ en el invierno, respectivamente. El porcentaje de morbilidad en distintos varió desde casi un $0.17 \%$ en agosto a un $3.8 \%$ en marzo. Los resultados de la distribución mensual de PPR se muestran en la figura 3.

Con base en los resultados del modelado espacial, en la provincia de Chahar Mahal y Batjarí, la enfermedad se observó con mayor gravedad en la ciudad de Borujen, en la población de Borujrn. En Ardal y Naghan existieron otros dos puntos focales de la enfermedad. El riesgo de enfermedad por PPR en más del cincuenta por ciento de la provincia es inferior al 30\% (Figura 4). 
PPR prevalence from 2009 to 2014 was $2.1 \%, 2.59 \%, 0.7 \%, 0.49 \%, 1.08 \%, 1.73 \%$ respectively. Seasonal distribution of PPR infection was $2.6 \%$ in the spring, $1.55 \%$ in the summer, 0.32 per\% in the autumn and $1.73 \%$ in the winter, respectively. The means of morbidity percentage in different months has been variable of almost $0.17 \%$ in August to $3.8 \%$ in March. The results of monthly distribution of the PPR have been shown in figure 3 .

Based on the results of spatial modeling, in Chaharmahal and Bakhtiari province, the most severity of disease has been observed in Borujrn town of the city Borujen. Two other hotspots of disease have been existed in Ardal and Naghan. The risk of PPR disease in more than fifty percent of the province is less than $30 \%$ (Figure 4 ).

Monthly distribution of PPR disease (2009-2014)

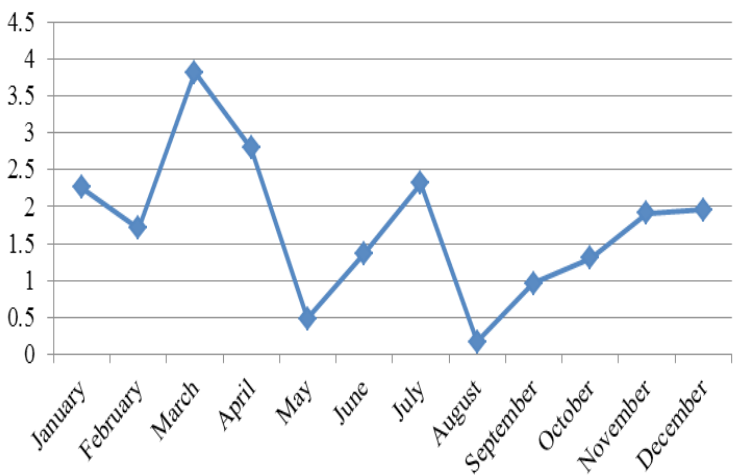

Figure 3. Monthly distribution of PPR disease between 2009-2014 in Chaharmahal and Bakhtiari

\section{DISCUSSION}

Peste des petits ruminants (PPR) is usually extremely contagious as well as morbillivirus disease affecting sheep and goats (16). For effective control of PPR, a full understanding of the disease epidemiology is obligatory. PPR eradication depends on rapid and precise diagnosis, and using of fast control measures. Due to the massive economic effects of PPR, it is absolutely essential to perform epidemiological surveys of this disease. In Iran, several PPR outbreaks were not accurately recorded due to inadequate animal disease reporting and surveillance systems. Measuring the clinical prevalence of PPR in different geographical areas of may be helpful for organizing disease control strategies and can be useful for determining the true infection rate. Longitudinal survey of PPR in Iran has not been performed

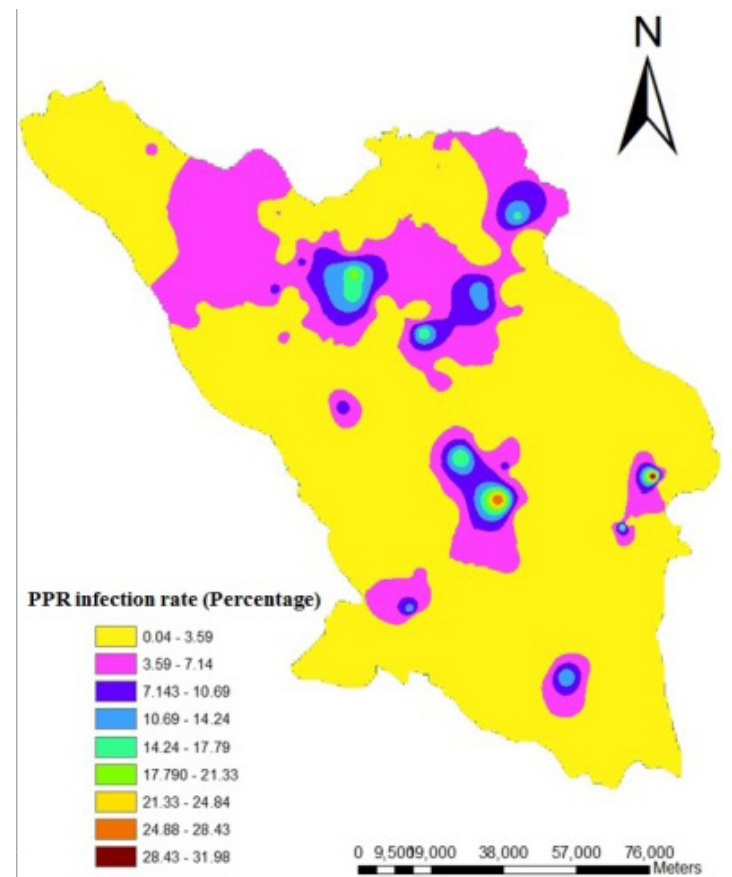

Figure 4. Spatial modeling of PPR disease between 20092014 in Chaharmahal and Bakhtiari, Iran.

\section{DISCUSIÓN}

La Peste de los pequeños rumiantes (PPR) es una enfermedad viral altamente contagiosa que se presenta en ovinos y caprinos (16). Para un control efectivo de la PPR, se requiere una plena comprensión epidemiologica de la enfermedad. La erradicación de la PPR depende de un diagnóstico rápido y preciso, y del uso medidas de control rápidas. Dados los enormes efectos económicos causados por la PPR, es absolutamente fundamental realizar estudios epidemiológicos acerca de esta enfermedad. En Irán, varios brotes de PPR no fueron reportados con exactitud debido a los precarios sistemas de notificación y vigilancia de enfermedades animales. Para organizar estrategias para el control de la enfermedad, medir la prevalencia clínica de la PPR en distintas zonas geográficas puede resultar útil para determinar la tasa de infección, además de ser útil para determinar las tasas de infección reales. No se han realizado estudios longitudinales de PPR en Irán

El presente estudio presenta información de carácter introductorio acerca de brotes confirmados de PPR o de infección entre ovinos y caprinos en Irán entre el 2009 y 2014. En Irán se están realizando programas de vacunación vigentes, lo cual alterará la epidemiología de la PPR, particularmente la distribución de la enfermedad. Los ovinos y caprinos son los huéspedes naturales de la PPRV, siendo los caprinos más susceptibles que los ovinos (17). En el 
The present study has provided introductory information about confirmed PPR outbreaks or infection among sheep and goats in Iran between 2009 and 2014. Current vaccination programs are being accomplished in Iran which will alter PPR epidemiology, particularly distribution of the disease. Sheep and goats are the natural host of PPRV and goats are more susceptible than sheep (17). In this study, greater PPR positivity was observed in samples from goats than sheep. Soundararajan et al (18) also showed a higher mortality rate among infected goats than sheep in a large organized farm. However, higher seroprevalence in sheep as compared to goats has been observed in some other studies $(13,19-22)$ Although sheep and goats may not vary significantly in qualifications of disease incidence but a higher mortality rate in PPRV infected goats than in sheep has been established (23).

Based on difference in the virulence of field strains from both species, sheep might have greater innate resistance to clinical development of the disease than goats. This hypothesis appears to be supported by data previously collected during several outbreaks of PPR. It is also possible that the PPRV prefers goat over sheep when both of these natural hosts are reared connectedly. Higher recovery rate in sheep leads to longevity as a result of which a higher population of sheep shows PPRV positivity than goats (13). Moreover, due to higher productivity rate of goats, herd is quickly replaced by young ones which are more susceptible to PPRV (11). Findings in present study are in agreement with Balamurugan et al (24) and Rashid et al (25) who found a lower PPRV prevalence in sheep than goats $(24,25)$.

The reported prevalence of PPR in goats at present study was $1.37 \%$ and was in opposite with the results higher prevalence reported by Al-Dubaib (26), Islam et al (27), Rahman et al (28), Sarker and Islam (29), Swai et al (30), Ozkul et al (28) and Singh et al (12) who reported $50.27 \%$ and $20.57 \%$ in Bangladesh, $55 \%$ in Black Bangle goat(BAU), 55.1\% seroprevalence in Saudi Arabia, $49.5 \%$ seroprevalence in Tanzania, $15.36 \%$ seroprevalence in Pakistan, $20 \%$ in Turkey and $32.4 \%$ in India $(21,28,32-$ $34)$. This variation might be due to different geographical location, research time, and different management actions.

In Chaharmahal and Bakhtiari province, goats are reared mostly by nomads. These animals are free-range or pasture-grazed and receive minimum veterinary care, which may further augment the chances of acquiring PPR infection. presente estudio se observó una mayor positividad de PPR en muestras de caprinos que de ovinos. Soundararajan et al (18) también indicaron una mayor tasa de mortalidad en caprinos infectados que en ovinos infectados en una granja organizada de gran tamaño. Sin embargo, otros estudios han observado una mayor seroprevalencia en ovinos comparados con caprinos (13,19-22). Aunque puede no haber una variación significativa en las tasas de incidencia de la enfermedad, se ha establecido una mayor mortalidad en los caprinos infectados con PPRV que en ovinos (23).

Con base en la diferencia en virulencia de las cepas de campo entre ambas especies, es posible que los caprinos gocen de una mayor resistencia innata al desarrollo clínico de la enfermedad que los ovinos. Esta hipótesis parece estar respaldada por información previa recolectada durante varios brotes de PPR. También es posible que la PPRV prefiera a los caprinos que a los ovinos cuando ambos huéspedes naturales son criados de forma conexa. Además, la mayor tasa de recuperación presente en ovinos conduce a la longevidad, lo que resulta en que una mayor población ovina sea positiva para PPRV que su contraparte caprina (13). Además, debido a una mayor tasa de productividad en caprinos, el rebaño se reemplaza rápidamente con jóvenes que son más susceptibles a la PPRV (11). Los hallazgos del presente estudio concuerdan con los de Balamurugan et al (24) y Rashid et al (25), quienes encontraron una menor prevalencia de PPRV en ovinos que en caprinos $(24,25)$.

La prevalencia de PPR en cabras que se reporta en el presente estudio es de $1,37 \%$ a diferencia de los resultados con mayor prevalencia reportados por Al-Dubaib (26), Islam et al (27), Rahman et al (28), Sarker e Islam (29), Swai et al (30), Ozkul et al (28) y Singh et al (12), quienes reportaron $50,27 \%$ y $20,57 \%$ en Bangladesh, $55 \%$ en cabra negra (Black Bangle), seroprevalencia del 55,1\% en Arabia Saudita, seroprevalencia del $49,5 \%$ en Tanzania, seroprevalencia del $15,36 \%$ en Pakistán, $20 \%$ en Turquía y $32,4 \%$ en India $(21,28,32-34)$. Esta variación puede estar ocasionada por las distintas ubicaciones geográficas, los tiempos de investigación y las distintas acciones de manejo.

Los nómadas son los principales criadores de caprinos en la provincia de Chahar Mahal y Batjarí. Estos son animales de pastoreo libre o alimentados a base de pasto que reciben cuidados veterinarios mínimos, lo que puede aumentar las posibilidades de que éstos adquieran infección por PPR. Los animales son arreados de un lugar a otro durante el período de escasez, y el movimiento de los animales y los factores climáticos que favorecen la supervivencia y la propagación del virus podrían crear una predisposición a la ocurrencia estacional 
During the lean period, the animals are flocked from one place to another and animal movement and climatic factors that favor the survival and spread of the virus might predispose temporal occurrence of PPR outbreaks. Trading small ruminants at market places, where animals from different areas are brought into close contact with one another, also promotes PPRV transmission (13).

When prevalence were analyzed according to geographic region, high positivity was observed in animals from Farsan (1.41\%) and Kiar $(1.12 \%)$ compared to other towns. Using chisquare test there weren't significant differences between infection levels in different cities studied, as well as in different types of animals $(p>0.05)$.

Since 1995, a number of PPR outbreaks have been reported in different provinces of Iran with variable morbidity and mortality rates (7). Nargesi et al (31) reported that PPR prevalence in Mash-had province of Iran was $59.52 \%$ in 2012 , from these positive samples $72.09 \%$ were belonged to sheep and $27.91 \%$ were belonged to goat (34).

In a survey performed by Shadmanesh et al in 2014 (30), PPR prevalence in Eghlid City of Iran was compered between goat and sheep. The highest prevalence rate in the flock of sheep was in the Haji-Abad area (25\%) and lowest contamination rate was in Jadval-Now area $(3.45 \%)$. In flocks of goats, the highest contamination rate was in Bidsobhan area (45\%) and lowest contamination rate was in SharadEigder area (2.5\%). They interpreted that high density of the flocks in some regions, the neglect of hygiene, quarantine, and migratory herds (herds of nomads) in these areas are causes of more contamination (33).

Differences in disease prevalence could be due to the sample size, animal movements and nutritional deficiencies (21). Little nutrition may increase disease incidence due decreased immune resistance. Since relatively few numbers of samples from some towns were tested, differences in PPR prevalence among sheep and goats from these various towns may not be significant. Low rates of positivity recorded in Ben and Kouhrang towns in sheep and goats. This could be due to small sample sizes, surrounded movement of the animals.

Spatial modeling of PPR in Iran has not been reported. This study showed the average distance of the nearest PPR cluster to the center of each province was $160 \mathrm{~km}$ and none of the de brotes de PPR. El comercio de pequeños rumiantes en mercados, en donde hay un estrecho contacto entre animales de distintas zonas, también promueve la transmisión de PPRV (13).

Al analizar la prevalencia por región geográfica, se observó una alta positividad en animales de Farsan $(1.41 \%)$ y Kiar $(1.12 \%)$ en comparación con otros pueblos. Las pruebas de chi-cuadrado aplicadas no mostraron diferencias significativas entre los niveles de infección ni entre los distintos tipos de animales de las diferentes ciudades bajo estudio $(p>0.05)$.

Desde 1995 se han notificado varios brotes de PPR con tasas variables de morbilidad y mortalidad en distintas provincias de Irán (7). Nargesi et al (31) reportaron que la prevalencia de PPR en la provincia iraní de Mash-ha fue de $59.52 \%$ en 2012, el $72.09 \%$ de las muestras positivas pertenecían a ovinos y el $27.91 \%$ pertenecían a caprinos.

Un estudio realizado por Shadmanesh et al en 2014 (30) comparó la prevalencia de PPR entre caprinos y ovinos en la ciudad iraní de Eghlid. La mayor tasa de prevalencia en rebaños de ovinos se presentó en la zona de Haji-Abad (25\%) y la menor tasa de contaminación se presentó en la zona de Jadval-Now (3.45\%). En rebaños de caprinos, la mayor tasa de contaminación se presentó en la zona de Bidsobhan (45\%) y la menor tasa de contaminación se presentó en la zona de Sharad-Eigder (2.5\%). Los autores interpretan que en algunas regiones la alta densidad de los rebaños, una higierne descuidada, las cuarentenas y los rebaños migratorios (manadas de nómadas) presentes en estos lugares son causas de mayor contaminación (33).

Las diferencias en la prevalencia de la enfermedad podrían ser atribuídas al tamaño de la muestra, a los movimientos de los animales y a deficiencias nutricionales (21). La escaza nutrición puede aumentar la incidencia de la enfermedad a causa de una disminución en la resistencia inmune. Puesto que en algunas ciudades se obtuvo una cantidad de muestras relativamente baja, la diferencia en la prevalencia de PPR entre ovinos y caprinos de las distintas poblaciones puede no ser significativa. Re registraron bajas tasas de positividad en ovinos y caprinos.en las ciudades de Ben y Kouhrang. Lo anterior puede ser debido a las pequeñas cantidades de muestras pequeños, y el movimiento rodeado de los animales.

No se han realizado estudios espaciales de PPR en Irán El presente estudio indicó que la distancia promedio de los brotes (clusters) de PPR más cercanos al centro de cada provincia es de160 km, y que ningún punto focal de PPR estuvo ubicado en las cabeceras provinciales. La interpretación del 
PPR hotspots were located in the provincial centers. Interpretation of spatial modeling is different from interpretation of the results of statistical analysis. As the map shows, one of the main hotspot of the PPR is Borujen and the disease is seen within 200 kilometers away from this city and the incidence decreased with increasing distance.

The situation is likewise Ardal and Naghan. This distribution pattern is dependent on issues such as animal husbandry systems, knowledge of animal farmers, humidity, rainfall and temperature in these areas is as well as the possibility of further distribution of the disease by animal movements (33).

This study indicated that the prevalence of PPR in Chaharmahal and Bakhtiari was $1.37 \%$ from 2009 to 2014. During these years, incidence of PPR disease in Chaharmahal and Bakhtiari had chaotic process. Earlier studies (7) indicated that the disease is distributed, which could likely be ascribed to agro-climatic conditions, socio-economic factors, and migration patterns of small ruminants. PPR outbreaks among sheep and goats in Iran can occur at any time of the year, but are most common during the wet (February and May) or dry (April and October) months in Chaharmahal and Bakhtiari province (21). Rainy season is more susceptible to occurrence of the disease as compared with dry season (34). When the temporal distribution of PPR outbreaks was analyzed in the current study, increased numbers of outbreaks occurred during the winter and spring seasons. These results are in coordination with study performed by Sarker and Islam (2011) who observed higher prevalence in winter season (13). This could be due to limited availability of feed during a part of theses seasons, close contact, inhalation of aerosol produced by sneezing and coughing of infected animals, direct contact with ocular, nasal, oral secretions, feces, fomites such as bedding, water and feed troughs (31). However, Taylor (33) believed that increased PPR rate might be due to the increased introduction of sensitive young animals to the flocks rather than a seasonal surge in viral activity. This researcher also reported that PPR is mostly observed during the wet season. Moreover, Wosu $(31,32)$ found that disease incidence peaks during the dry season rather than the rainy season. Inclement dry cold weather during October coupled with poor nutrition over this period promotes the spread of PPR.

The prevalence of PPR in dairy- Beef cattle farms $(25 \%)$ was higher than other farms. The modelado espacial es distinta a la interpretación de los resultados del análisis estadístico. Como lo muestra el mapa, uno de los principales puntos focales de PPR es Borujen en donde la enfermedad se puede ver a 200 kilómetros de distancia la ciudad y en donde la incidencia disminuyó a medida que aumentaba la distancia.

La situación es la misma en Ardal y Naghan. Este patrón de distribución depende de factores tales como sistemas de ganadería, el conocimiento que poseen los agricultores, la humedad, las precipitaciones y la temperatura en estas zonas, así como de la posibilidad de una mayor distribución de la enfermedad causada por los movimientos de los animales.

El presente estudio indicó que la prevalencia de PPR en Chahar Mahal y Batjarí, fue de $1.37 \%$ entre 2009 y 2014. La incidencia de la enfermedad de PPR en Chahar Mahal y Batjarí pasó por proceso caótico durante dichos años. Existen estudios anteriores (7) que indican que la enfermedad está distribuida, lo que probablemente podría atribuirse a condiciones agroclimáticas, factores socioeconómicos y a los patrones migratorios de pequeños rumiantes. Los brotes de PPR entre ovinos y caprinos en Irán pueden ocurrir en cualquier época del año, pero son más comunes durante los meses húmedos (febrero y mayo) o secos (abril y octubre) en la provincia de Chahar Mahal y Batjarí (21). La estación lluviosa es más susceptible a la aparición de la enfermedad en comparación con la estación seca (34). Cuando se analizó la distribución temporal de los brotes de PPR en el presente estudio, se produjo un mayor número de brotes durante las temporadas de invierno y primavera. Estos resultados concuerdan con el estudio realizado por Sarker e Islam (2011), quienes observaron una mayor prevalencia en la temporada de invierno (13). Lo anterior puede ser debido a la disponibilidad limitada de alimentos durante parte de estas estaciones, al contacto cercano, a la inhalación de aerosoles producidos por animales infectados por medio de estornudos o tos, al contacto directo con secreciones oculares, nasales, orales y heces, además de fómites tales como el lecho, los abrevaderos de agua y los comederos (31). Sin embargo, Taylor (33) consideró que, en lugar de un aumento estacional en la actividad viral, el aumento en la tasa de PPR podría ser atribuido una mayor introducción de animales jóvenes y sensibles a las bandadas. Este investigador también informó que la PPR se observa principalmente durante la temporada húmeda. Por otra parte, Wosu $(31,32)$ encontró que la incidencia de la enfermedad alcanza un pico durante la estación seca en lugar de hacerlo en la temporada de lluvias. Los climas inclementes, fríos y secos que se dan en octubre junto con una nutrición deficiente promueven la propagación propagación de PPR. 
high potential for cross-species transmission of PPRV from small ruminants to cattle in areas where these species live in close proximity suggests that monitoring such livestock communities would be useful for detecting any changes in the apparent pathogenicity of PPRV, including the possible emergence of PPR as a disease in cattle populations. The incidence of PPR in rural farms was higher $(1.42 \%)$ than urban farms $(0.92 \%)$. This variation may be due to poor management of traditional herders. The difference between the rate of disease in different livestock systems evaluated by chisquare analysis and there was a statistically significant difference $(p<0.05)$.

National eradication strategy can only be based on latest data on prevalence of PPR in various parts of Iran. The present study was carried out to determine current prevalence of the disease in small ruminants in various districts of Chaharmahal and Bakhtiari province. Our findings provide evidence of widespread PPR endemicity in Chaharmahal and Bakhtiari that may be due to variations in husbandry practices in different geographical regions, agro-climatic conditions, and animal migration. Vaccination against PPR has been practiced in Iran to control the disease (6). Currently available PPR vaccines and preventive strategies against PPR in Chaharmahal and Bakhtiari, especially in hotspots are very important and have been recommended for a collaborative nation-wide control programs.

\section{Acknowledgments}

This study was conducted in as a research project (No.: 170/1) of the faculty of veterinary medicine, Shahrekord University. The authors are thankful for the financial support of Shahrekord University.
La prevalencia de PPR fue mayor en granjas vacunas ganaderas y lecheras ( $25 \%$ ) que en otras granjas. EI alto potencial de transmisión cruzada de PPRV entre especies, desde pequeños rumiantes hasta ganado las en áreas en donde viven estas especies en estrecha proximidad sugiere que sería útil monitorear dichas comunidades ganaderas para detectar cualquier cambio en la aparente patogenicidad de PPRV, incluyendo una posible aparición de la enfermedad de PPR en poblaciones vacunas. La incidencia de PPR en granjas rurales fue mayor $(1.42 \%)$ que en las fincas urbanas $(0.92 \%)$. Esta variación puede estar causada por un mal manejo por parte de los pastores tradicionales. Se evaluó la diferencia entre las tasas de enfermedad de distintos sistemas pecuarios por medio de un análisis chi-cuadrado y se encontró una diferencia estadísticamente significativa $(p<0.05)$.

La estrategia nacional de erradicación sólo puede basarse en los datos más recienetes de la prevalencia de PPR en distintas partes de Irán. El presente estudio se realizó para determinar la prevalencia actual de la enfermedad en pequeños rumiantes de diversos distritos de la provincia de Chahar Mahal y Batjarí. Nuestros resultados evidencian la presencia de una endemicidad de PPR generalizada en Chahar Mahal y Batjarí, lo cual se le puede atribuir a variaciones en las prácticas de cría, las condiciones agro-climáticas y en la migración de animales que existen entre las diferentes regiones geográficas. En Irán se ha llevado a cabo una vacunación contra la PPR para controlar la enfermedad (6). Las vacunas contra la PPR y las estrategias preventivas contra la misma que se encuentran disponibles en la actualidad en Chahar Mahal y Batjarí son de gran importancia, particularmente en los puntos focales, y han sido recomendadas para un programa de control colaborativo a nivel nacional.

\section{Agradecimientos}

El presente estudio se realizó como proyecto de investigación (Nro.: 170/1) de la Facultad de Medicina Veterinaria de la Universidad de Shahrekord. Los autores agradecen el apoyo financiero por parte de la Universidad de Shahrekord.

\section{REFERENCES}

1. Zahur $A B$, Ullah $A$, Irshad $H$, Farooq $M S$, Hussain $M$, Jahangir $M$. Epidemiological investigations of a peste des petits ruminants (PPR) outbreak in Afghan sheep in Pakistan. Pakistan Vet J 2009; 29(4):174-178.
2. Diallo A, Minet $C$, Le Goff $C$, Berhe G, Albina $E$, Libeau $G$, Barrett $T$. The threat of peste des petits ruminants: progress in vaccine development for disease control. Vaccine 2007; 25(30):5591-5597. 
3. Venkataramanan R, Bandyopadhyay SK, Oberoi MS. Present status and strategies for the control of transboundary and other economically important animal diseases in India: a review. Indian J Anim Sci 2005; 75(4):456-464.

4. Jones TC, Hunt RD, King NW. Diseases caused by viruses. In: Veterinary Pathology, 6th edition. William and Wilkins, a Waverly Company. Philadelphia, USA; 1997.

5. Shaila MS, Shamaki $D$, Forsyth MA, Diallo A, Goatley L, Kitching RP, et al. Geographic distribution and epidemiology of peste des petits ruminants viruses. Virus Res 1996; 43(2):149-153.

6. Ebrahimzadeh Leylabadlo $H$, Samadi Kafi $H$, Asgharzadeh $M$, Peste des petits ruminants (PPR): A Serious Threat for Wild Life. ABCmed 2016; 4(2):49-50.

7. Abubakar M, Khan HA, Arshed MJ, Hussain M, Ali Q. Peste des Petits Ruminants (PPR): disease appraisal with global and Pakistan perspective. Small Rum Res 2011; 96(2):1-10.

8. Banik SC, Podder SC, Samad MA, Islam MT. Sero-surveillance and immunization in sheep and goats against Peste des petits ruminants in Bangladesh. Bangl J Vet Med 2008; 6(2):185-190.

9. Abubakar M, Jamal SM, Hussain M, Ali Q. Incidence of peste des petits ruminants (PPR) virus in sheep and goat as detected by immuno-capture ELISA (Ic ELISA) Small Ruminant Res 2008; 75:256-9.

10. Athar H, Muhammad G, Azim F, Shakoor A, Maqbool A, Chaudhary NI. An outbreak of peste des petits ruminants-like disease among goats in Punjab (Pakistan). Pak Vet J 1995; 15(1):140-143.

11. Hussain $M$, Muneer $M$, Jahangir $M, A$ wan $A H$, Khokhar MA, Zahur AB, et al. Chromatographic strip technology: A pen-side test for the rapid diagnosis of pests des petits ruminants in sheep and goats. Online J Biol Sci 2003; 3(1):1-7.

12. Singh RP, Saravanan $P$, Sreenivasa BP, Singh RK, Bandyopadhyay SK. Prevalence and distribution of peste des petits ruminants virus infection in small ruminants in India. Rev Sci Tech 2004; 23(3):807-819.
13. Banyard AC, Wang $Z$, Parida $S$. Peste des petits ruminants virus, eastern Asia. Emerg Infect Dis $2014 ; 20(12): 2176-8$.

14. OIE, 2015. Global control and eradication of peste des petits ruminants. http://www.oie. int/eng/PPR2015/doc/PPR-Advocacy-EN.pdf

15. Mahapatra M, Parida S, Baron M, Barrett T. Matrix protein and glycoproteins $\mathrm{F}$ and $\mathrm{H}$ of peste-des-petits-ruminants virus function better as a homologous complex. J Gen Virol 2006; 87:2021-2029

16. Awa DN, Njoya A, Ngo-Tama AC. Economics of prophylaxis against peste des petits ruminants and gastrointestinal helminthosis in small ruminants in north Cameroon. Trop Anim Health Prod 2000; 32 (6): 391-403.

17. Soundararajan C, Sivakumar T, Ramesh S, Muthukrishnan S, Palanidorai R. Peste des petits ruminants among sheep and goats in an organized farm in Tamil Nadu. Indian Vet J 2006; 83(2):1045-1047.

18. Khan HA, Siddique M, Abubakar M, Arshad MJ, Hussain M. Prevalence and distribution of peste des petitsruminants virus infection in small ruminants. Small Rumin Res 2008; 79(2):152-157.

19. Munir M, Saeed A, Abubakar M, Kanwal S, Berg M. Molecular characterization of Peste des Petits Ruminants viruses from outbreaks caused by unrestricted movements of small ruminants in Pakistan. Transbound Emerg Dis 2015; 62(1):108-114.

20. Raghavendra AG, Gajendragad MR, Sengupta $\mathrm{PP}$, Patil SS, Tiwari CB, Balumahendiran M, et al. Seroepidemiology of peste des petits ruminants in sheep and goats of southern peninsular India. Rev sci tech Off int Epiz 2008; 27(3):861-867.

21. Abubakar M, Arshed MJ, Hussain M, Ali Q. Evidence of peste des petits ruminants in serology of sheep and goats from Sindh, Pakistan. Transbound Emerg Dis 2011; 58(2):152- 156.

22. Soundararajan C, Sivakumar T, Ramesh S, Muthukrishnan S, Palanidorai R. Peste des petits ruminants among sheep and goats in an organized farm in Tamil Nadu. Indian Vet J 2006; 83(10):1045-1047. 
23. Balamurugan $V$, Saravanan $P$, Sen $A$, Rajak $K K$, Bhanuprakash V, Krishnamoorthy $P$, et al. Sero-epidemiological study of peste des petits ruminants in sheep and goats in India between 2003 and 2009. Rev sci tech Off int Epiz 2011; 30(3):889-896.

24. Rashid A, Asim M, Hussain A. Seroprevalence of peste des petits ruminants (PPR) virus in goats, sheep and cattle at livestock production research institute Bahadurnagar Okara. J Anim Plant Sci 2008; 18(4):114-116.

25. Al-Dubaib MA. Peste des petitis ruminants morbillivirus infection in lambs and young goats at Qassim region, Saudi Arabia. Trop Anim Health Prod 2009; 41(2):217-220.

26. Islam MS, Khan MSI, Kader HA, Begum MR, Asgar MA. Prevalence of PPR of goat and their response to antibiotic treatment at Mirzaganj Upazila of Patuakhali Distrtict. J Environ Sci and Natural Resources 2012; 5(2):81-184.

27. Rahman MA, Shadmin I, Noor M, Parvin R, Chowdhury EH, Islam MR. Peste des petits ruminants virus infection of goats in Bangladesh: Pathological investigation, molecular detection and isolation of the virus. The Bangladesh Veterinarian 2011; 28(1):1-7.

28. Sarker S, Islam MH. Prevalence and Risk Factor Assessment of Peste des petits ruminants in Goats in Rajshahi, Bangladesh. Vet World 2011; 4(12):546-549.
29. Swai ES, Kapaga A, Kivaria F, Tinuga D, Joshua G, Sanka P. Prevalence and distribution of Peste des petits ruminants virus antibodies in various districts of Tanzania. Vet Res Commun 2009; 33:927-936.

30. Ozkul A, Akea Y, Alkan F. Prevalence, distribution, and host range of peste des petits ruminants virus, Turkey. Emerg Infect Dis 2002; 8(7):708-712.

31. Nargesi I, Pourshaban Kolveiri M, Maghsoudi M. Survey on Peste des Petits Ruminants (PPR) in small ruminants. Ann Appl Biol 2012; 3(10):4842-4844.

32. Wosu LO, Okiri JE, Enwezor PA. Optimal Time for Vaccination Against Peste Des Petits Ruminants (PPR) Disease in Goats in Humid Tropical Zone in Southern Nigeria. Arch Roum Pathol Exp Microbiol 1990; 49(3):283-291.

33. Shadmanesh, A. Sero-prevalence of Peste des Petits Ruminants (PPR) virus in sheep and goats in north parts of Iran. CIBTech J Zoology 2014; 3(3):13-17.

34. Samad MA. Poshu Palon O Chikitsavidya (Animal Husbandry and Medicine). 2nd Ed, Published by M. Bulbul, Bangladesh Agricultural University campus, Mymenshingh: Bangladesh; 2000. 